\title{
Reactions of the Mixed-metal Clusters Prepared from Tungsten Acetylide Complexes; X-Ray Structural Analyses of Two Novel Butterfly Clusters with 60 Valence Electrons
}

\section{Yun Chi, * a Hsiu-Fu Hsu, a Shie-Ming Pengt ${ }^{b}$ and Gene-Hsiang Lee ${ }^{b}$}

a Department of Chemistry, National Tsing Hua University, Hsinchu 30043, Taiwan

b Department of Chemistry, National Taiwan University, Taipei 10764, Taiwan

Reaction of $\mathrm{WL}(\mathrm{CO})_{3} \mathrm{C} \equiv \mathrm{CPh}$ and $\mathrm{Os}_{3}(\mathrm{CO})_{10}\left(\mathrm{C}_{2} \mathrm{R}_{2}\right)$ produced $\mathrm{WOs}_{3} \mathrm{~L}(\mathrm{CO})_{9}\left(\mu_{3}-\mathrm{CPh}\right)(\mathrm{CCRCR}), \mathrm{L}=\mathrm{Cp}, \mathrm{R}=\mathrm{Tol}\left(p-\mathrm{MeC} \mathrm{H}_{4}\right)$ $1 \mathrm{a} ; \mathrm{L}=\mathrm{C}_{5} \mathrm{Me}_{5}, \mathrm{R}=\mathrm{Me}, 1 \mathrm{~b}$; treatment of complexes 1 with ditolylacetylene yielded planar clusters WOs $_{3} \mathrm{~L}(\mathrm{CO})_{8}\left(\mu_{3}-\mathrm{CPh}\right)[\mathrm{C}(\mathrm{Tol}) \mathrm{C}(\mathrm{Tol}) \mathrm{CCRCR}], \mathrm{L}=\mathrm{Cp}, \mathrm{R}=\mathrm{Tol}, \mathbf{2 a} ; \mathrm{L}=\mathrm{C}_{5} \mathrm{Me}_{5}, \mathrm{R}=\mathrm{Me}$, $\mathbf{2 b}$; complex $2 \mathbf{b}$ underwent reversible loss of $\mathrm{CO}$ to produce an unsaturated cluster $\mathrm{WOs}_{3} \mathrm{C}_{5} \mathrm{Me}_{5}(\mathrm{CO})_{7}\left(\mu_{3}-\mathrm{CPh}\right)[\mathrm{CMeCMeCC}(\mathrm{Tol}) \mathrm{C}(\mathrm{Tol})] \mathbf{3 b}$; thermolysis of $\mathbf{3 b}$ in refluxing xylene induced the rearrangement of the cluster core, giving another unsaturated complex $\mathbf{4 b}$ with identical molecular formula; complexes $\mathbf{1 a}, \mathbf{3 b}$ and $\mathbf{4 b}$ have been examined by $\mathrm{X}$-ray diffraction studies.

We have recently devised syntheses of several polynuclear cluster complexes from reactions of group 6 mononuclear metal acetylide and hydride complexes with group 8 cluster

$\dagger$ For crystallographic enquiries. complexes, such as $\mathrm{Os}_{3}(\mathrm{CO})_{10}(\mathrm{NCMe})_{2}, \quad \mathrm{Ru}_{3}(\mathrm{CO})_{12}$ $\mathrm{Ru}_{3}(\mathrm{CO})_{10}\left(\mu_{3}-\mathrm{NPh}\right)$ and $\mathrm{Ru}_{3}(\mathrm{CO})_{10}(\mu-\mathrm{H})(\mu-\mathrm{COMe})$, and examined the crystal structures and reactivities of the new heterometallic clusters prepared. ${ }^{1}$ We report here the preparation of $\mathrm{Os}_{3} \mathrm{~W}$ clusters $\mathrm{WOs}_{3} \mathrm{~L}(\mathrm{CO})_{9}\left(\mu_{3}-\mathrm{CPh}\right)(\mathrm{CCRCR})$, $\mathrm{L}=\mathrm{Cp}, \mathrm{R}=\mathrm{Tol}\left(p-\mathrm{MeC}_{6} \mathrm{H}_{4}\right), \mathbf{1 a} ; \mathrm{L}=\mathrm{C}_{5} \mathrm{Me}_{5}, \mathrm{R}=\mathrm{Me}$, $\mathbf{1 b}$ via 


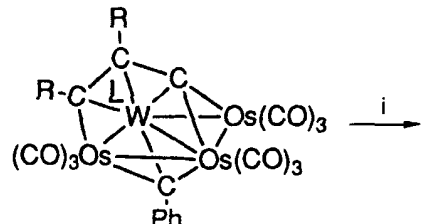

1 a $R=$ Tol, $L=C p$

b $\mathrm{R}=\mathrm{Me}, \mathrm{L}=\mathrm{C}_{5} \mathrm{Me}_{5}$

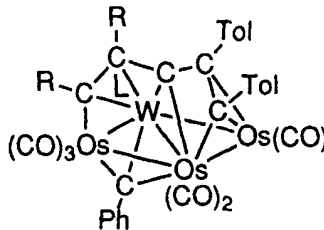

2 a $R=T$ ol, $L=C p$

b $R=M e, L=C_{5} M_{5}$
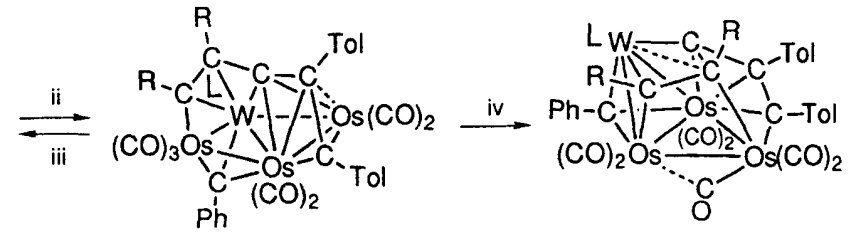

3b $\mathrm{R}=\mathrm{Me}, \mathrm{L}=\mathrm{C}_{5} \mathrm{Me}_{5}$

4b $R=M e, L=C_{5} M_{5}$

Scheme $1 \mathrm{i}$, excess $\mathrm{C}_{2} \mathrm{Tol}_{2}$; ii, $-\mathrm{CO}, 140^{\circ} \mathrm{C}, 20 \mathrm{~min}$; iii, $+\mathrm{CO}, 110^{\circ} \mathrm{C}, 5 \mathrm{~min}$; iv, $140^{\circ} \mathrm{C}, 65 \mathrm{~min}$

cleavage of the acetylide $\mathrm{C}-\mathrm{C}$ triple-bond and some results of the subsequent reactivity studies. The reaction of $\mathbf{1 b}$ with ditolylacetylene coupled the alkyne to the coordinated $\mathrm{C}_{3}$ hydrocarbon, giving one saturated cluster compound with a multi-site bound $\mathrm{C}_{5}$ ligand. On heating this compound loses a $\mathrm{CO}$ ligand, yielding two novel, 60-electron, coordinatively unsaturated cluster compounds, sequentially. ${ }^{2}$ Our study reported in this paper highlights the role and action of the accessory ligands in responding to the creation of coordination unsaturation.

Treatment of tungsten acetylide $\mathrm{WCp}(\mathrm{CO})_{3} \mathrm{C} \equiv \mathrm{CPh}^{3}$ with the triosmium alkyne complex $\mathrm{Os}_{3}(\mathrm{CO})_{10}\left(\mathrm{C}_{2} \mathrm{Tol}_{2}\right)^{4}$ in refluxing toluene $\left(110^{\circ} \mathrm{C}, 30 \mathrm{~min}\right)$ yielded a novel heterometallic cluster $(\mathbf{1 a}, 20 \%)$, while the analogous derivative (1b, 9\%) was prepared from the reaction between $\mathrm{WC}_{5} \mathrm{Me}_{5}(\mathrm{CO})_{3^{-}}$ $\mathrm{C} \equiv \mathrm{CPh}$ and $\mathrm{Os}_{3}(\mathrm{CO})_{10}\left(\mathrm{C}_{2} \mathrm{Me}_{2}\right)^{5}$ under similar conditions (Scheme 1). Both complexes $\mathbf{1 a}$ and $\mathbf{b}$ were initially characterized by mass, IR and NMR spectroscopy; $\ddagger$ in addition, complex la was examined by X-ray diffraction in an attempt to establish the exact molecular structure. $\$$ The ORTEP diagram and some bond parameters are presented in Fig. 1. Consistent with its molecular structure, we deduce that the formation of these $\mathrm{Os}_{3} \mathrm{~W}$ clusters involves two unique processes. One is the scission of the acetylide carbon-carbon triple-bond and the other is the coupling of the acetylide $\alpha$-carbon with the coordinated alkyne ligand, producing the observed alkylidyne and $\mathrm{C}_{3}$ hydrocarbon ligands, respectively.

Reactions with disubstituted alkyne have also been examined. The reaction of $1 \mathrm{a}$ with excess ditolylacetylene in toluene

\footnotetext{
$\ddagger$ Spectral data for 1a: MS (FAB, $\left.{ }^{192} \mathrm{Os},{ }^{184} \mathrm{~W}\right) \mathrm{m} / \mathrm{z} 1384\left(\mathrm{M}^{+}\right)$; IR $\left(\mathrm{C}_{6} \mathrm{H}_{12}\right) v(\mathrm{CO}) / \mathrm{cm}^{-1} 2077 \mathrm{~s}, 2048 \mathrm{vs}, 2036 \mathrm{~m}, 2018 \mathrm{~s}, 1997 \mathrm{vw}, 1974 \mathrm{~m}$, $1969 \mathrm{~m}$ and $1909 \mathrm{w} ;{ }^{1} \mathrm{H}$ NMR (400 MHz, $\left.\mathrm{CDCl}_{3}, 294 \mathrm{~K}\right) \delta$ 7.24-6.75 $(\mathrm{m}, 13 \mathrm{H}), 5.49(\mathrm{~s}, 5 \mathrm{H}), 2.33(\mathrm{~s}, 3 \mathrm{H})$ and $2.19(\mathrm{~s}, 3 \mathrm{H})$. For $1 \mathrm{~b}: \mathrm{MS}$ (FAB, $\left.{ }^{184} \mathrm{~W},{ }^{192} \mathrm{Os}\right), m / z 1302\left(\mathrm{M}^{+}\right)$. IR $\left(\mathrm{C}_{6} \mathrm{H}_{12}\right) v(\mathrm{CO}) / \mathrm{cm}^{-1} 2072 \mathrm{~s}$, 2040vs, 2032m, 2012s, 1991vw, 1970m, 1952s and 1912br, w; ${ }^{1}$ H NMR $\left(400 \mathrm{MHz}, \mathrm{CD}_{2} \mathrm{Cl}_{2}, 294 \mathrm{~K}\right) \delta 7.09\left(\mathrm{t}, 2 \mathrm{H}, J_{\mathrm{H}-\mathrm{H}} 6.8 \mathrm{~Hz}\right), 6.70(\mathrm{t}, 1 \mathrm{H}$, $\left.J_{\mathrm{H}-\mathrm{H}} 7.2 \mathrm{~Hz}\right), 6.91\left(\mathrm{~d}, 1 \mathrm{H}, J_{\mathrm{H}-\mathrm{H}} 7.4 \mathrm{~Hz}\right), 6.84\left(\mathrm{~d}, 1 \mathrm{H}, J_{\mathrm{H}-\mathrm{H}} 7.8 \mathrm{~Hz}\right)$, $3.21(\mathrm{~s}, 3 \mathrm{H}), 2.07(\mathrm{~s}, 3 \mathrm{H})$ and $1.80(\mathrm{~s}, 15 \mathrm{H}) ;{ }^{13} \mathrm{C} \mathrm{NMR}(100 \mathrm{MHz}$, $\left.\mathrm{CD}_{2} \mathrm{Cl}_{2}, 294 \mathrm{~K}\right), \delta 187.8,185.6,181.3,180.2,177.2,176.2(3 \mathrm{C}), 172.7$ and $239.5\left(J_{\mathrm{W}-\mathrm{C}} 111 \mathrm{~Hz}, \mu_{3}-\mathrm{CPh}\right)$. Satisfactory elemental analyses were obtained for both 1a and $\mathbf{b}$.
}

$\S$ Crystal data for 1a: $\mathrm{C}_{38} \mathrm{H}_{24} \mathrm{O}_{9} \mathrm{Os}_{3} \mathrm{~W}_{1}, M=1379.05$, monoclinic, space group $P 2_{1} / n, a=19.440(7), b=9.655(2), c=19.976(6) \AA, \beta=$ $105.85(3)^{\circ}, V=3607(2) \AA^{3}, Z=4, D_{\mathrm{c}}=2.540 \mathrm{~g} \mathrm{~cm}^{-3}, \mathrm{~F}(000)=2503$, Nonius CAD-4 diffractometer with graphite-monochromated Mo-K $\alpha$ radiation, $\lambda=0.70930 \AA, \mu(\mathrm{Mo}-\mathrm{K} \alpha)=13.85 \mathrm{~mm}^{-1}$. The min. and max. transmission factors are 0.416 and $0.997,6342$ unique reflections were measured, and 4603 reflections with $I>2.0 \sigma(I)$ were used in refinement. Refinement of 75 atoms and 461 parameters converged to $R_{\mathrm{f}}=0.037$ and $R_{\mathrm{w}}=0.032$, goodness of fit $(\mathrm{GOF})=1.89$. Atomic coordinates, bond lengths and angles, and thermal parameters have been deposited at the Cambridge Crystallographic Data Centre for 1a, $\mathbf{3 b}$ and $\mathbf{4 b}$. See Notice to Authors, Issue No. 1. $\left(110^{\circ} \mathrm{C}, 50 \mathrm{~h}\right)$ led to the isolation of a dark green complex (2a, $53 \%)^{6}$ and unreacted starting material $1 \mathrm{a}(35 \%)$. On the other hand, reaction of the analogous compound $1 \mathbf{b}$ with ditolylacetylene in refluxing xylene solvent $\left(140^{\circ} \mathrm{C}, 30 \mathrm{~min}\right)$ produced three cluster compounds $\mathbf{2 b}$ (yellowish green), $\mathbf{3 b}$ (red-brown) and $\mathbf{4 b}$ (brown) in 14, 41 and $22 \%$ yields, respectively, in addition to about $8 \%$ starting material $\mathbf{1 b}$ (Scheme 1). These cluster compounds were separated by TLC and purified by recrystallization, although we have observed that the silica gel tends to accelerate the decomposition of $\mathbf{3 b}$ and $\mathbf{4 b}$. The structure of $\mathbf{2 b}$ is closely related to $\mathbf{2 a}$ as indicated by its spectral data, whereas the FAB mass and ${ }^{13} \mathrm{C}$ NMR data suggest that both $\mathbf{3 b}$ and $\mathbf{4 b}$ possess one carbonyl ligand less than that of complex $\mathbf{2 b}$. 1

Red-brown, air-stable, plate-shaped crystals of $\mathbf{3 b}$ were obtained from a solution of $\mathrm{CH}_{2} \mathrm{Cl}_{2}$-heptane at room temperature and an X-ray diffraction study was carried out.** An ORTEP diagram is shown in Fig. 2, which also provides selected bond distances. The molecule contains a planar triangulated rhomboidal arrangement with $\mathrm{W}$ and Os(2) atoms at the bridgehead position, the dihedral angle between the W-Os(2)-Os(1) and W-Os(2)-Os(3) planes being $171.8(1)^{\circ}$. There is an alkylidyne ligand $\left(\mu_{3}-\mathrm{CPh}\right)$ which is associated with the face defined by atoms Os(2), Os(3) and W and, on the opposite side of the alkylidyne ligand, is a $\mathrm{C}_{5}$ hydrocarbon ligand which is coordinated to all four metal atoms. The central carbon atom $\mathrm{C}(12)$ is linked to three metal

I Spectral data for $\mathbf{2 b}$ : MS (FAB, $\left.{ }^{184} \mathrm{~W},{ }^{192} \mathrm{Os}\right), \mathrm{m} / \mathrm{z} 1480\left(\mathrm{M}^{+}\right)$ $\mathrm{IR}\left(\mathrm{C}_{6} \mathrm{H}_{12}\right) v(\mathrm{CO}) / \mathrm{cm}^{-1} 2066 \mathrm{~s}, 2029 \mathrm{vs}, 2008 \mathrm{~s}, 1992 \mathrm{~m}, 1964 \mathrm{~m}, 1959 \mathrm{~s}$, $1950 \mathrm{~m}$ and $1943 \mathrm{w} ;{ }^{1} \mathrm{H}$ NMR $\left(400 \mathrm{MHz}, \mathrm{CD}_{2} \mathrm{Cl}_{2}, 250 \mathrm{~K}\right) \delta 7.74(\mathrm{~d}, 1 \mathrm{H}$ $\left.J_{\mathrm{H}-\mathrm{H}} 8.2 \mathrm{~Hz}\right), 7.20-7.09(\mathrm{~m}, 5 \mathrm{H}), 6.99\left(\mathrm{t}, 1 \mathrm{H}, J_{\mathrm{H}-\mathrm{H}} 7 \mathrm{~Hz}\right), 6.86-6.77$ $(\mathrm{m}, 6 \mathrm{H}), 3.40(\mathrm{~s}, 3 \mathrm{H}), 2.32(\mathrm{~s}, 3 \mathrm{H}), 2.19(\mathrm{~s}, 3 \mathrm{H}), 1.80(\mathrm{~s}, 15 \mathrm{H})$ and 1.37 (s, 3H); ${ }^{3} \mathrm{C}$ NMR $\left(100 \mathrm{MHz}, \mathrm{CD}_{2} \mathrm{Cl}_{2}, 296 \mathrm{~K}\right): \delta 189.8,187.7,182.3$ (3C, br) $180.9,178.6,173.9$ and $247.2\left(J_{\mathrm{W}-\mathrm{C}} 118 \mathrm{~Hz}, \mu_{3}-\mathrm{CPh}\right)$. For $3 \mathbf{b}$ : MS (FAB, $\left.{ }^{184} \mathrm{~W},{ }^{192} \mathrm{Os}\right), \mathrm{m} / \mathrm{z} 1452\left(\mathrm{M}^{+}\right)$. IR $\left(\mathrm{C}_{6} \mathrm{H}_{12}\right) \vee(\mathrm{CO}) / \mathrm{cm}^{-1}$ 2064s, 2004vs, 1959s, 1940 s and $1878 \mathrm{~m} ;{ }^{1} \mathrm{H}$ NMR $\left(400 \mathrm{MHz}, \mathrm{CD}_{2} \mathrm{Cl}_{2}\right.$, $294 \mathrm{~K}) \delta 7.22\left(\mathrm{~d}, 2 \mathrm{H}, J_{\mathrm{H}-\mathrm{H}} 8 \mathrm{~Hz}\right), 7.12(\mathrm{~m}, 2 \mathrm{H}), 7.03\left(\mathrm{~d}, 2 \mathrm{H}, J_{\mathrm{H}-\mathrm{H}} 8\right.$ $\mathrm{Hz}), 7.01-6.95(\mathrm{~m}, 5 \mathrm{H}), 6.67\left(\mathrm{~d}, 2 \mathrm{H}, J_{\mathrm{H}-\mathrm{H}} 8 \mathrm{~Hz}\right), 3.15(\mathrm{~s}, 3 \mathrm{H}), 2.32(\mathrm{~s}$, $3 \mathrm{H}), 2.29(\mathrm{~s}, 3 \mathrm{H}), 1.87(\mathrm{~s}, 15 \mathrm{H})$ and $1.23(\mathrm{~s}, 3 \mathrm{H}) ;{ }^{13} \mathrm{C} \mathrm{NMR}(100 \mathrm{MHz}$ $\left.\mathrm{CD}_{2} \mathrm{Cl}_{2}, 250 \mathrm{~K}\right) \delta 209.2,189.3,189.2,186.1,181.3,178.4,171.9(\mathrm{CO})$ and $257.0\left(J_{\mathrm{W}-\mathrm{C}} 113 \mathrm{~Hz}, \mu_{3}-\mathrm{CPh}\right)$. For $4 \mathrm{~b}: \mathrm{MS}\left(\mathrm{FAB}, 184 \mathrm{~W},{ }^{192 \mathrm{Os}}\right)$ $\mathrm{m} / \mathrm{z} 1452\left(\mathrm{M}^{+}\right)$. IR $\left(\mathrm{C}_{6} \mathrm{H}_{12}\right) v(\mathrm{CO}) / \mathrm{cm}^{-1} 2066 \mathrm{~s}, 2029 \mathrm{vs}, 2008 \mathrm{~s}, 1992 \mathrm{~m}$, $1964 \mathrm{~m}, 1959 \mathrm{~s}, 1950 \mathrm{~m}$ and $1943 \mathrm{w} ;{ }^{1} \mathrm{H}$ NMR $\left(400 \mathrm{MHz}, \mathrm{CD}_{2} \mathrm{Cl}_{2}, 294 \mathrm{~K}\right)$ $\delta 7.37\left(\mathrm{~d}, 2 \mathrm{H}, J_{\mathrm{H}-\mathrm{H}} 7.7 \mathrm{~Hz}\right), 7.27\left(\mathrm{t}, 2 \mathrm{H}, J_{\mathrm{H}-\mathrm{H}} 7.7 \mathrm{~Hz}\right), 7.14(\mathrm{~d}, 2 \mathrm{H}$ $\left.J_{\mathrm{H}-\mathrm{H}} 8.0 \mathrm{~Hz}\right), 7.02-6.91(\mathrm{~m}, 7 \mathrm{H}), 3.27(\mathrm{~s}, 3 \mathrm{H}), 2.28(\mathrm{~s}, 3 \mathrm{H}), 2.27$ $(\mathrm{s}, 3 \mathrm{H}), 2.09(\mathrm{~s}, 3 \mathrm{H})$ and $1.61(\mathrm{~s}, 15 \mathrm{H})$; satisfactory elemental analyses were obtained for compounds $\mathbf{2 b}, \mathbf{3 b}$ and $\mathbf{4 b}$.

** Crystal data for 3b: $\mathrm{C}_{45} \mathrm{H}_{40} \mathrm{O}_{7} \mathrm{Os}_{3} \mathrm{~W}_{1}, M=1447.26$, monoclinic, space group $P 2 / n, a=14.532(2), b=18.485(2), c=15.654(2) \AA, \beta=$ $91.52(1)^{\circ}, V=4203(1) \AA^{3}, Z=4, D_{\mathrm{c}}=2.287 \mathrm{~g} \mathrm{~cm}^{-3}, \mathrm{~F}(000)=2671$, $\mu(\mathrm{Mo}-\mathrm{K} \alpha)=11.88 \mathrm{~mm}^{-1}$. The min. and max. transmission factors are 0.396 and $0.999,5482$ unique reflections were measured, and 3523 reflections with $I>2.0 \sigma(I)$ were used in refinement. Refinement of 96 atoms and 501 parameters converged to $R_{\mathrm{f}}=0.040$ and $R_{\mathrm{w}}=0.036$, $\mathrm{GOF}=1.81$. 


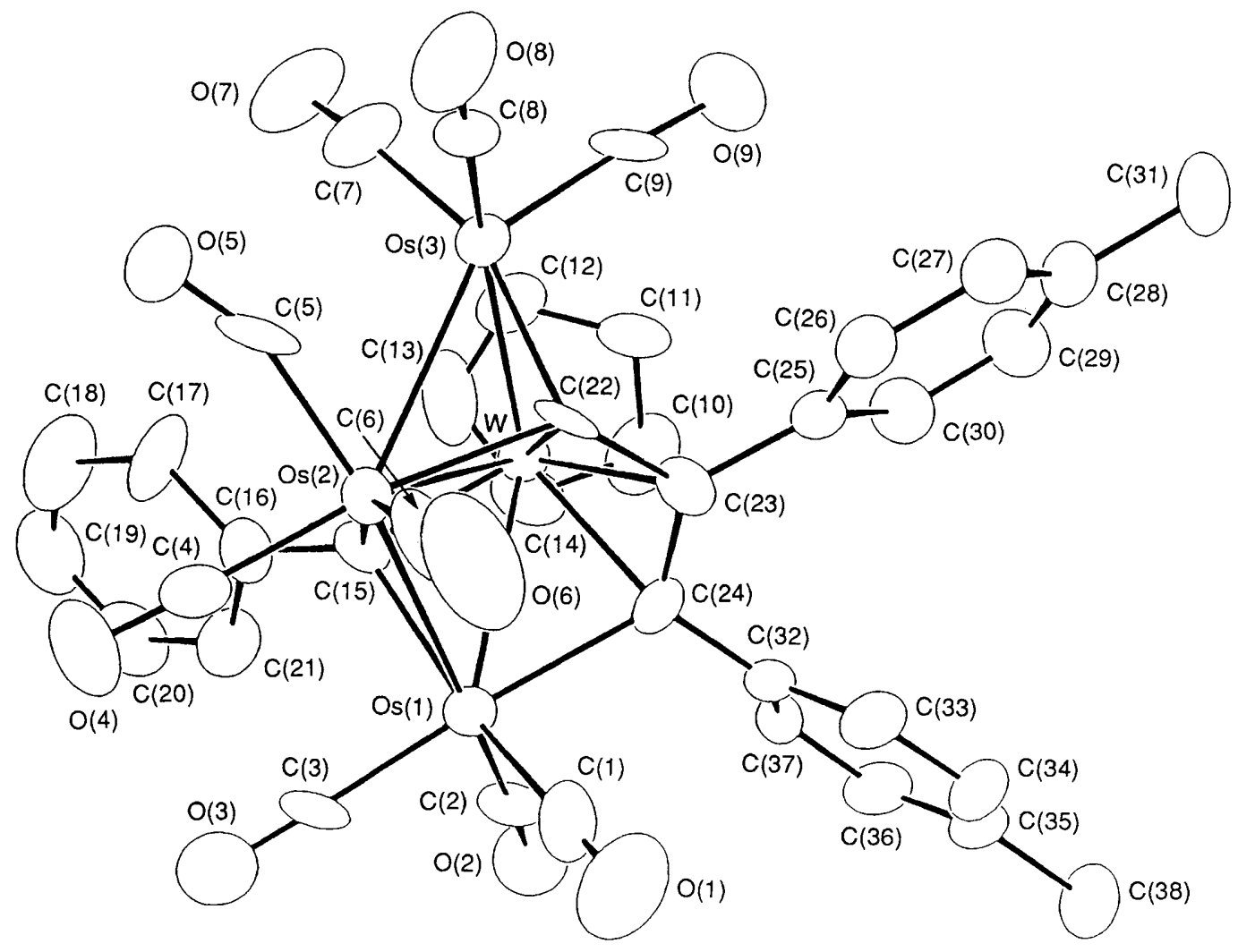

Fig. 1 The molecular drawing of 1a. Bond lengths $(\AA ̊)$ : Os(1)-Os(2) 2.769(1), Os(1)-W 2.830(1), Os(2)-W 2.849(1), Os(3)-W 2.857(1), $\mathrm{Os}(2)-\mathrm{Os}(3)$ 2.818(1), Os(1)-C(15) 2.16(1), Os(2)-C(15) 2.23(1), W-C(15) 1.96(1), Os(2)-C(22) 2.11(1), Os(3)-C(22) 1.97(1), W-C(22) 2.15(1), W-C(23) 2.29(1), Os(1)-C(24) 2.18(1), W-C(24) 2.21(1), C(22)-C(23) 1.44(2) and $\mathrm{C}(23)-\mathrm{C}(24)$ 1.48(2). Dihedral angle between the planes Os(1)-Os(2)-W and Os(2)-Os(3)-W 162.1(1) .

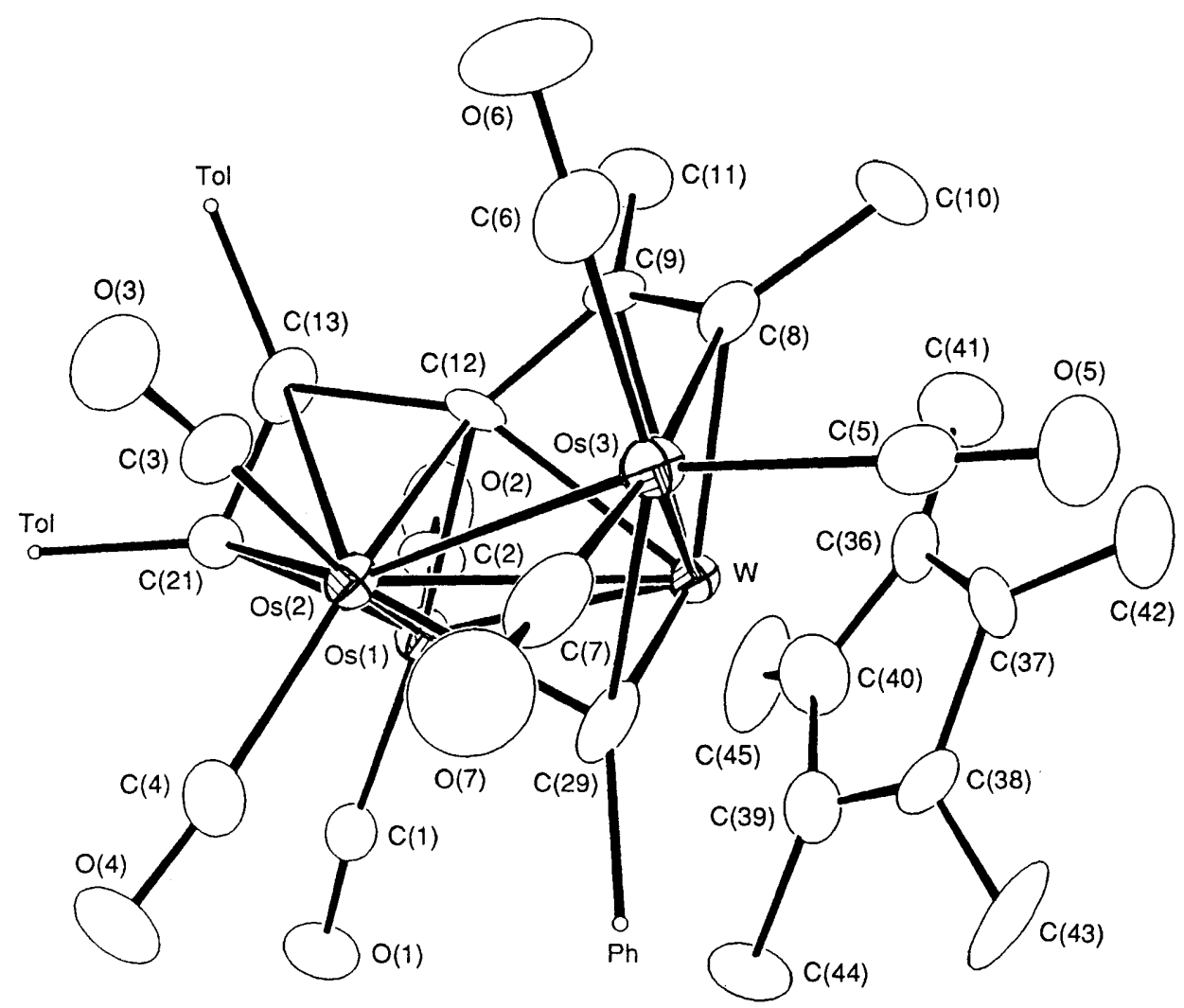

Fig. 2 The molecular drawing of 3b. Bond lengths ( $\AA$ ): Os(1)-Os(2) 2.803(1), Os(1)-W 2.681(1), Os(2)-W 2.887(1), Os(3)-W 2.873(1), $\mathrm{Os}(2)-\mathrm{Os}(3)$ 2.770(1), Os(2)-C(29) 2.19(2), Os(3)-C(29) 2.15(2), W-C(29) 2.04(2), Os(3)-C(8) 2.24(2), W-C(8) 2.27(2), W-C(9) 2.36(2), W-C(12) 2.19(2), Os(1)-C(12) 2.28(2), Os(2)-C(12) 2.17(2), Os(2)-C(13) 2.30(2), Os(1)-C(13) 2.56(2), Os(1)-C(21) 2.03(2), Os(2)-C(21) 2.14(2), $C(8)-C(9)$ 1.32(3), $C(9)-C(12)$ 1.44(2), $C(12)-C(13)$ 1.54(3) and $C(13)-C(21)$ 1.39(3). Dihedral angle between the planes Os(1)-Os(2)-W and Os(2)-Os(3)-W 171.8(1). 


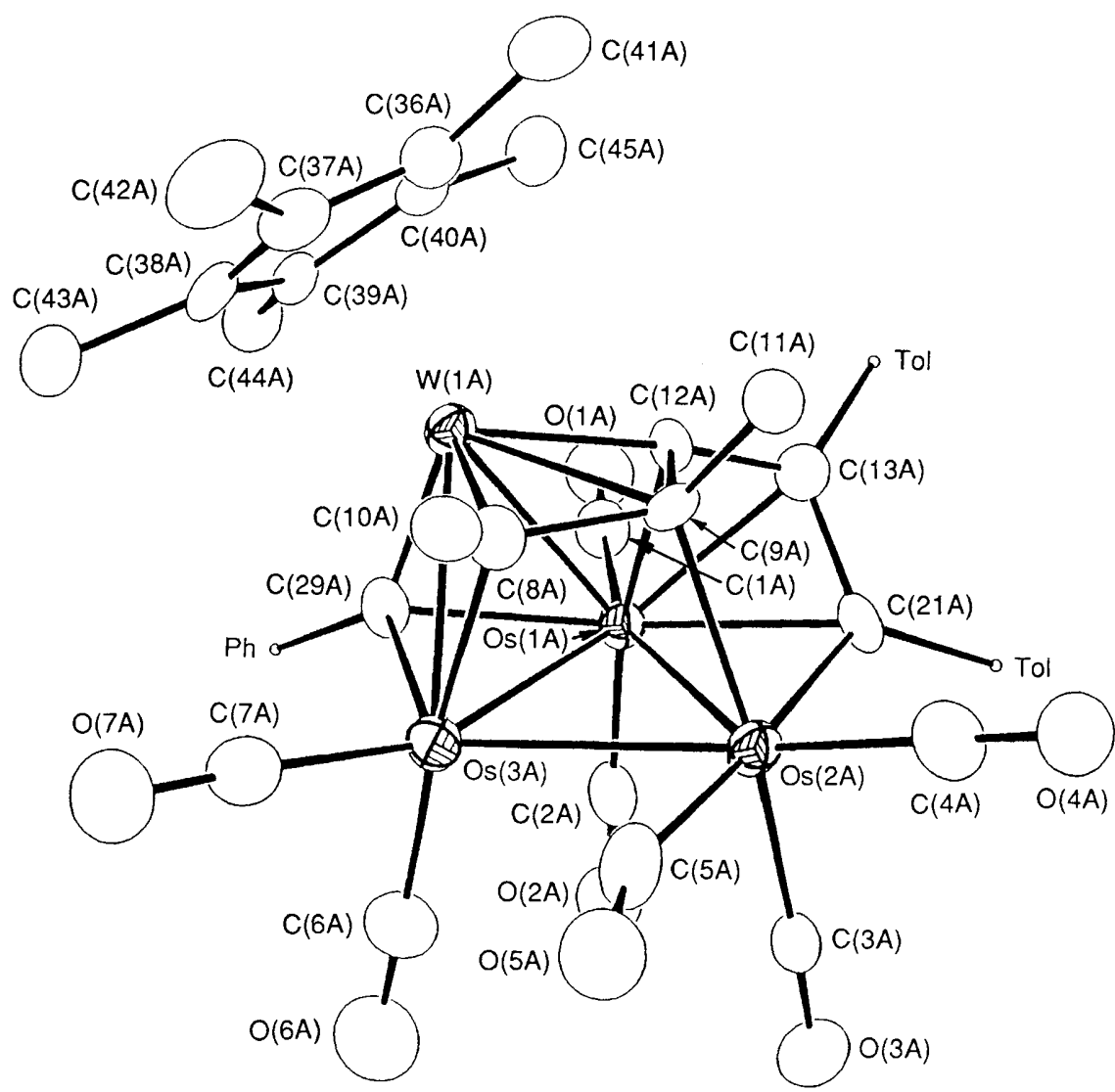

Fig. 3 The molecular drawing of 4 b. Bond lengths $(\AA)$ : Os(1A)-Os(2A) 2.771(2), Os(1A)-Os(3A) 2.803(2), Os(1A)-W(1A) 2.791(2), $\mathrm{Os}(2 \mathrm{~A})-\mathrm{Os}(3 \mathrm{~A}) 2.723(2), \mathrm{Os}(3 \mathrm{~A})-\mathrm{W}(1 \mathrm{~A}) 2.794(2), \mathrm{Os}(1 \mathrm{~A})-\mathrm{C}(29 \mathrm{~A}) 2.18(2), \mathrm{Os}(3 \mathrm{~A})-\mathrm{C}(29 \mathrm{~A}) 2.04(2), \mathrm{W}(1 \mathrm{~A})-\mathrm{C}(29 \mathrm{~A}) 2.03(2), \mathrm{Os}(3 \mathrm{~A})-\mathrm{C}(8 \mathrm{~A})$ 2.19(2), W(1A)-C(8A) 2.02(2), Os(2A)-C(9A) 2.24(2), W(1A)-C(9A) 2.40(2), Os(1A)-C(12A) 2.17(2), W(1A)-C(12A) $1.94(2), O s(1 \mathrm{~A})-$ $\mathrm{C}(13 \mathrm{~A})$ 2.22(2), Os(2A)-C(21A) 2.14(2), Os(1A)-C(21A) 2.25(2), C(8A)-C(9A) 1.54(3), C(9A)-C(12A) 1.57(3), C(12A)-C(13A) 1.44(3), $\mathrm{C}(13 \mathrm{~A})-\mathrm{C}(21 \mathrm{~A}) 1.49(3)$, Os(2A)-C(5A) $1.92(3)$ and $\mathrm{Os}(3 \mathrm{~A})-\mathrm{C}(5 \mathrm{~A}) 2.48(3)$. Dihedral angle between the planes $\mathrm{Os}(1 \mathrm{~A})-\mathrm{Os}(2 \mathrm{~A})-\mathrm{Os}(3 \mathrm{~A})$ and Os(1A)-Os(3A)-W(1A) $108.9(1)^{\circ}$.

atoms $\mathrm{W}, \mathrm{Os}(1)$ and $\mathrm{Os}(2)$, and two $\mathrm{C}_{2}$ alkyne fragments. The $\mathrm{C}(9)-\mathrm{C}(8)$ fragment is linked to the Os(3) atom via a $\sigma$-bonding and to the $\mathrm{W}$ atom via a $\pi$-bonding, whereas the $\mathrm{C}(13)-\mathrm{C}(21)$ fragment is coordinated to Os(1) atom and the Os(2) atom via a $\sigma$-bonding and a $\pi$-bonding.

Basically, the core arrangement of $\mathbf{3 b}$ is similar to that of the structurally characterized $\mathbf{2 a}$, except that the 'wing-tip' metal atom Os(1) in this case carries two $\mathrm{CO}$ ligands and that the $\mathrm{W}-\mathrm{Os}(1)$ bond $[2.681(1) \AA]$ is much shorter than the respective $\mathrm{W}-\mathrm{Os}$ distance of 2a [3.004(1) $\AA$ ].$^{6}$ Moreover, the conformation of the $\mathrm{C}(13)-\mathrm{C}(21)$ fragment, with respect to the Os(1)-Os(2)-C(12) triangle, is reminiscent of the unusual $\mu_{3}$ $\left(\eta^{2}-\perp\right)$ alkyne arrangement observed in the unsaturated, 46-electron trinuclear alkyne complexes, ${ }^{7}$ such as $\mathrm{Fe}_{3}(\mathrm{CO})_{9}\left(\mathrm{C}_{2} \mathrm{Ph}_{2}\right)^{8}$ and $\mathrm{Cp}_{2} \mathrm{~W}_{2} \mathrm{Fe}(\mathrm{CO})_{6}\left(\mathrm{C}_{2} \mathrm{Tol}_{2}\right) .{ }^{9}$ It is possible that the electron-donating ability of the $\mathrm{C}_{5} \mathrm{Me}_{5}$ ligand, the perpendicular arrangement of the alkyne fragment and the potential multiple-bonding character of the $\mathrm{W}-\mathrm{Os}(1)$ bond contribute substantially to the remarkable stability of $\mathbf{3 b}$.

Crystals of $\mathbf{4 b}$ suitable for X-ray diffraction study were obtained from a solution of $\mathrm{CCl}_{4}$-heptane. According to the $\mathrm{X}$-ray analysis, $\dagger^{\dagger}$ the unit cell contains two crystallographic-

$\dagger$ Crystal data for $\mathbf{4 b}: \mathrm{C}_{45} \mathrm{H}_{40} \mathrm{O}_{7} \mathrm{Os}_{3} \mathrm{~W}_{1}, M=1447.26$, monoclinic, space group $P \overline{1}, a=11.179(5), b=17.689(4), c=24.41(2) \AA, \alpha=$ $99.36(5), \beta=96.92(5), \gamma=88.75(3)^{\circ}, V=4728(5) \AA^{3}, Z=4, D_{c}=$ $2.033 \mathrm{~g} \mathrm{~cm}^{-3}, \mathrm{~F}(000)=2671, \mu(\mathrm{Mo}-\mathrm{K} \alpha)=10.57 \mathrm{~mm}^{-1}$. The min. and max. transmission factors are 0.478 and $1.000,12326$ unique reflections were measured, and 8668 reflections with $I>2.0 \mathrm{\sigma}(I)$ were used in refinement. Refinement of 192 atoms and 940 parameters converged to $R_{\mathrm{f}}=0.048$ and $R_{\mathrm{w}}=0.057, \mathrm{GOF}=3.68$ ally distinct, but structurally similar molecules. An ORTEP diagram of one of these molecules is shown in Fig. 3. This molecule displays a 'butterfly' arrangement with Os $(2 \mathrm{~A})$ and $\mathrm{W}(1 \mathrm{~A})$ defining the 'wing-tip' positions and with $\mathrm{Os}(1 \mathrm{~A})$ and Os(3A) atoms occupying the 'hinge' positions. The alkylidyne ligand is located at the exterior of the Os(1A)-Os(3A)$\mathrm{W}(1 \mathrm{~A})$ surface, and the $\mathrm{C}_{5}$ hydrocarbon ligand now adopts an $\mathrm{S}$-shaped arrangement and is encapsulated in the interior of the butterfly core arrangement. Again, the $\mathrm{C}(8 \mathrm{~A})-\mathrm{C}(9 \mathrm{~A})$ alkyne fragment of the coordinated $\mathrm{C}_{5}$ ligand may also exhibit the uncommon $\mu_{3}\left(\eta^{2}-1\right)$ bonding character.

After completion of the structural assignment, the relationship between complexes $2,3 \mathrm{~b}$ and $\mathbf{4 b}$ can be readily understood and established. Thermolysis of 2a in xylene solution $\left(140^{\circ} \mathrm{C}, 60 \mathrm{~min}\right)$ is fraught with much decomposition. However, thermolysis of its $\mathrm{C}_{5} \mathrm{Me}_{5}$ analogue $\mathbf{2 b}$ under similar conditions $\left(140^{\circ} \mathrm{C}, 20 \mathrm{~min}\right)$ induced elimination of $\mathrm{CO}$ to produce $3 \mathbf{b}$ in $85 \%$ yield; as expected, exposure of the toluene solution of $3 \mathbf{b}$ to $\mathrm{CO}\left(1 \mathrm{~atm}, 110^{\circ} \mathrm{C}, 5 \mathrm{~min}\right)$ regenerated $2 \mathrm{~b}$ in nearly quantitative yield. Further heating of $\mathbf{3 b}$ in xylenes $(65$ $\mathrm{min}$ ) led to $4 \mathbf{b}$ in $25 \%$ yield, in addition to $48 \%$ unreacted $\mathbf{3 b}$. In contrast, carbonylation of $\mathbf{4 b}$ in refluxing toluene ( $1 \mathrm{~atm}$, $110^{\circ} \mathrm{C}, 45 \mathrm{~min}$ ) failed to produce its saturated, 62-electron precursor $\mathbf{2 b}$, but gave instead two additional cluster complexes. This result is clearly due to the fact that the metal skeleton has encountered extensive, irreversible rearrangement during the formation of $\mathbf{4 b}$.

We thank the National Science Council of the Republic of China for financial support of this research (Grant No. NSC80-0208-M007-60).

Received, 19th February 1991; Com. 1/00795E 


\section{References}

1 Y. Chi, F.-J. Wu, B.-J. Liu, C.-C. Wang and S.-L. Wang, J. Chem. Soc., Chem. Commun., 1989, 873; Y. Chi, G.-H. Lee, S.-M. Peng and B.-J. Liu, Polyhedron, 1989, 8, 2003; Y. Chi, D.-K. Hwang, S.-F. Chen and L.-K. Liu, J. Chem. Soc., Chem. Commun., 1989, 1540; Y. Chi, G.-H. Lee, S.-M. Peng and C.-H. Wu, Organometallics, 1989, 8, 1574; C.-H. Wu, Y. Chi, S.-M. Peng and G.-H. Lee, J. Chem. Soc., Dalton Trans., 1990, 3025; Y. Chi, G. Huttner and W. Imhof, J. Organomet. Chem., 1990, 384, 93; D.-K. Hwang, Y. Chi, S.-M. Peng and G.-H. Lee, J. Organomet. Chem., 1990, 389, C7.

2 D. M. P. Mingos and A. May, in The Chemistry of Metal Clusters, eds. D. F. Shriver, H. D. Kaesz and R. D. Adams, VCH; New York, 1990; ch. 2; R. D. Adams and I. T. Horvath, Prog. Inorg. Chem., 1985, 33, 127.
3 M. I. Bruce, M. G. Humphrey, J. G. Matisons, S. K. Roy and A. G. Swincer, Aust. J. Chem. 1984, 37, 1955.

4 M. Tachikawa, J. R. Shapley and C. G. Pierpont, J. Am. Chem. Soc., $1975,97,7172$

5 B. F. G. Johnson, R. Khattar, J. Lewis, P. R. Raithby and D. N. Smit, J. Chem. Soc., Dalton Trans., 1988, 1421.

6 Complex 2a was first prepared from the reaction between an acetylide cluster complex $\mathrm{WOs}_{3} \mathrm{Cp}(\mathrm{CO})_{11}(\mathrm{C} \equiv \mathrm{CPh})$ and ditolylacetylene, see: Y. Chi, C.-H. Wu, S.-M. Peng and G.-H. Lee, Organometallics, 1990, 9, 2305.

7 The cluster core of these 46-electron complexes can be rationalized to adapt a closo-trigonal bipyramidal arrangement in terms of Wade's rules, see: K. Wade, Adv. Inorg. Radiochem., 1976, 18, 1.

8 J. F. Bount, L. F. Dahl, C. Hoogzand and W. Hübel, J. Am. Chem. Soc., 1966, 88, 292.

9 L. Busetto, J. C. Jeffery, R. M. Mills, F. G. A. Stone, M. J. Went and P. Woodward. J. Chem. Soc., Dalton Trans., 1983, 101. 